\title{
A Novel Mutation in a Child with Atypical Wiskott-Aldrich Syndrome Complicated by Cytomegalovirus Infection
}

\author{
Sitomegalovirüs Enfeksiyonu ile Komplike Atipik Wiskott-Aldrich Sendromlu Bir Çocukta
} Yeni Bir Mutasyon

\author{
(D) Zühre Kaya1, (D) Cansu Muluk1, (D) Şule Haskoloğlu², (D) Lale Ş. Tufan³ \\ ${ }_{1}^{1}$ Gazi University Faculty of Medicine, Department of Pediatrics, Division Pediatric Hematology, Ankara, Turkey \\ ${ }^{2}$ Ankara University Faculty of Medicine, Department of Pediatric Allergy and Immunology, Ankara, Turkey \\ ${ }^{3}$ Ankara University Faculty of Medicine, Department of Forensic Medicine Forensic Genetics Laboratory, Ankara, Turkey
}

\section{To the Editor,}

We present the first described case of a young child with newly diagnosed Wiskott-Aldrich syndrome (WAS) caused by a novel mutation in the WAS gene, c.271C>T(p.091X), presenting with juvenile myelomonocytic leukemia (JMML)-like clinical features and cytomegalovirus (CMV) infection.

The proband, a 4-month-old boy, was referred to our hospital for evaluation of eczema, bicytopenia, leukocytosis, and splenomegaly, all of 2 months' duration. He also had a history of pneumonia. The boy's parents were not related, and there was a family history of early childhood deaths. Physical examination revealed splenomegaly and widespread eczema, and informed consent was obtained from the parents for Figure 1. Laboratory assessment revealed hemoglobin of $8.4 \mathrm{~g} / \mathrm{dL}$ and reticulocytes of $1.3 \%$, white blood count of $19,600 / \mathrm{mm}^{3}$ (35\% eosinophils, $15 \%$ monocytes on differential blood count), platelet count of $33,000 / \mathrm{mm}^{3}$, and mean platelet volume (MPV) of $10 \mathrm{fL}$. The direct Coombs test was positive for warm antibodies, and a peripheral blood smear revealed marked eosinophils, monocytes, and immature myeloid cells and giant platelets. Bone marrow examination showed myeloid hyperplasia with eosinophilia. Baseline immunoglobulin ( $\mathrm{lg}$ ) levels were normal (IgG $317 \mathrm{mg} / \mathrm{dL}, \lg A 14 \mathrm{mg} / \mathrm{dL}$, and IgM $87 \mathrm{mg} / \mathrm{dL}$ ). The patient was diagnosed with autoimmune hemolytic anemia and had additional diagnostic criteria that suggested JMML and WAS. He was started on prednisone at $1 \mathrm{mg} / \mathrm{kg}$ twice daily. Three weeks after initial presentation, he developed shortness of breath, fatigue, and palpitations. He developed a severe pulmonary infection that was successfully treated with trimethoprimsulfamethoxazole and ganciclovir. A PCR test for CMV was positive, with 9700 copies $/ \mathrm{mL}$. Molecular genetic analysis revealed a novel mutation in the WAS gene, c.271C>T(p.091X). The patient was diagnosed with WAS. He was scheduled for allogeneic stem cell transplantation from an unrelated donor.

WAS is a rare and potentially fatal disorder of $\mathrm{X}$-linked recessive inheritance that is characterized by recurrent sinopulmonary infections, eczema, and microthrombocytopenia. We report here a young child with newly diagnosed WAS complicated by CMV, with clinical and laboratory findings similar to JMML. Yoshimi et al. reported seven infant boys with WAS who initially presented with leukocytosis, monocytosis, and myeloid and erythroid precursors in their peripheral blood as well as bone marrow dysplasia [1]. The authors noted that the patients' MPV values were normal or high, which is incompatible with WAS. As we observed in our case, this clinical picture is indistinguishable from JMML. Affected patients may have variable clinical presentations due to disease-modifying genetic factors and different exposure to pathogens $[2,3,4]$. The causes of JMMLlike features in WAS patients are poorly understood. Recent reports suggest that such atypical features may be attributed to coexistence of viral infection or activation of WAS protein by

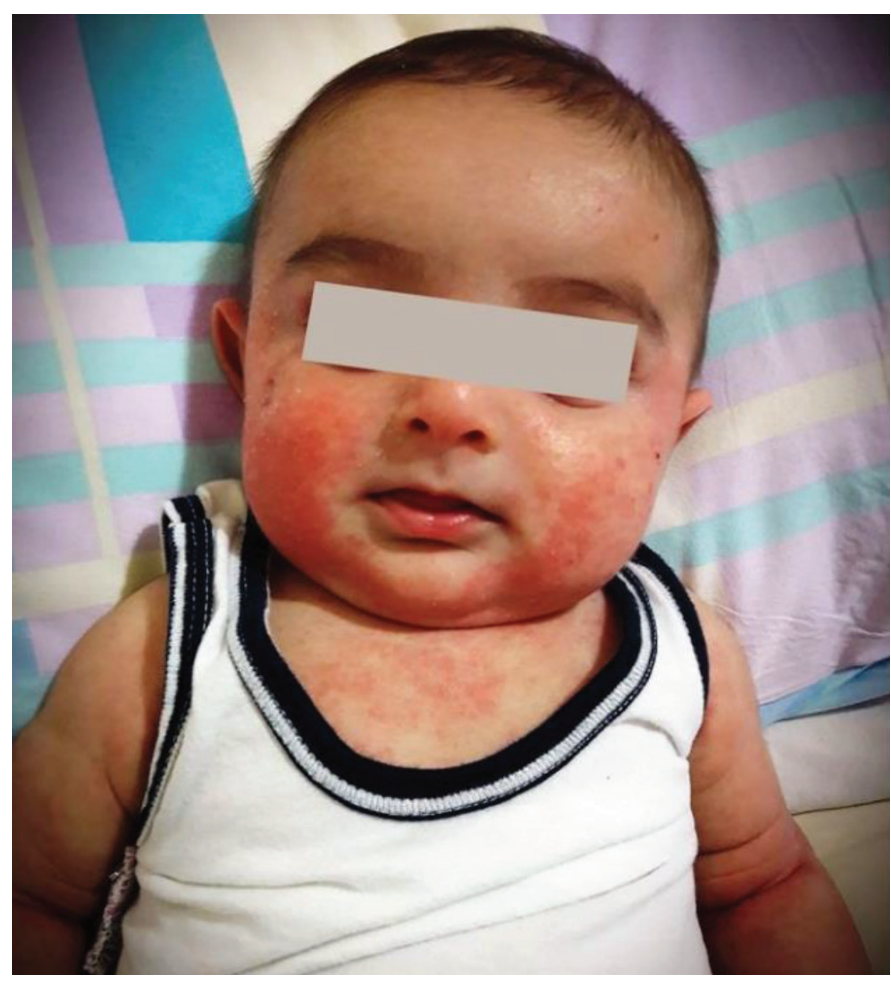

Figure 1. Physical examination revealed widespread eczema. 
a somatic mutation concomitant with RAS pathway mutations $[1,2,3,4,5]$. Based on these considerations, we believe that CMV infection was responsible for our patient developing a JMMLlike clinical picture and immune cytopenia. Although JMML mutational studies were not performed, persistent monocytosis, splenomegaly, and positive PCR results for CMV all support the diagnosis of CMV infection.

Our experience suggests that physicians should be aware of the potential development of immune cytopenias and JMML-like features in children with WAS who contract CMV infection.

Keywords: Wiskott-Aldrich syndrome, Juvenile myelomonocytic leukemia, Cytomegalovirus

Anahtar Sözcükler: Wiskott-Aldrich sendromu, Juvenil myelomonositik lösemi, Sitomegalovirüs

Informed Consent: The patient's parents provided written informed consent for the publication of the photograph.

Conflict of Interest: The authors of this paper have no conflicts of interest, including specific financial interests, relationships, and/or affiliations relevant to the subject matter or materials included.

\section{References}

1. Yoshimi A, Kamachi Y, Imai K, Watanabe N, Nakadate H, Kanazawa T, Ozono S, Kobayashi R, Yoshida M, Kobayashi C, Hama A, Muramatsu H, Sasahara Y, Jakob M, Morio T, Ehl S, Manabe A, Niemeyer C, Kojima S. WiskottAldrich syndrome presenting with a clinical picture mimicking juvenile myelomonocytic leukemia. Pediatr Blood Cancer 2013;60:836-841.

2. Leblebisatan G, Bay A, Mitsuiki N, Ohara O, Honma K, Imai K, Nonoyama S. Wiskott-Aldrich syndrome mutation in two Turkish siblings with $\mathrm{X}$-linked thrombocytopenia. Turk J Hematol 2011;28:139-141.

3. Sano H, Kobayashi R, Suzuki D, Yasuda K, Nakanishi M, Nagashima T, Yamada M, Kobayashi K. Wiskott-Aldrich syndrome with unusual clinical features similar to juvenile myelomonocytic leukemia. Int J Hematol 2012;96:279283.

4. Patil RB, Shanmukhaiah $C$, Jijina $F$, Bamborde $S$, Wasekar N, Toshniwal $M$, Mohite $A$, Patil V. Wiskott-Aldrich syndrome presenting with JMML-like blood picture and normal sized platelets. Case Rep Hematol 2016;2016:8230786

5. Coppe A, Nogara L, Pizzuto MS, Cani A, Cesaro S, Masetti R, Locatelli F, Te Kronnie G, Basso G, Bortoluzzi S, Bresolin S. Somatic mutations activating Wiskott-Aldrich syndrome protein concomitant with RAS pathway mutations in juvenile myelomonocytic leukemia patients. Hum Mutat 2018;39:579-587.

๑Copyright 2019 by Turkish Society of Hematology

Turkish Journal of Hematology, Published by Galenos Publishing House

Address for Correspondence/Yazışma Adresi: Zühre KAYA, M.D.,

Gazi University Faculty of Medicine, Department of Pediatrics, Division Pediatric Hematology, Ankara, Turkey

Phone : +903122026025

回解. E-mail : zuhrekaya@gmail.com ORCID-ID: orcid.org/0000-0002-3798-7246
Received/Geliş tarihi: May 31, 2018

Accepted/Kabul tarihi: July 02, 2018

DOI: $10.4274 /$ tjh.galenos.2018.2018.0187 